\title{
Bilateral Strategies and Development Agenda
}

Dr Chandrama Goswami ${ }^{\dagger}$

The recent visit of the Chinese president, $\mathrm{Xi}$ Xinping, to India has great significance for both the countries. The relationship between India and China has always been one of distrust, especially after the collapse of the friendship attempt made by the then Prime Minister of India, Pandit Jawaharlal Nehru, and Mao, India's decision to allow Tibet's Dalai-Lama (who Beijing considers a dangerous separatist) to reside in India, and the Sino-Indian Border War which followed in 1962. The border dispute still continues with both countries contesting land along their border in Ladakh and China's claim over India's north-eastern province of Arunachal Pradesh. India's concern also lies with the construction of the Chinese dam on the side of the River Brahmaputra. Each country is also skeptical about the other's relationship with Third World countries. In China's case, India's developing relationships with countries in the Asia-Pacific, especially Japan and the US; and in India's case, China's relationship with Pakistan. The Manmohan Singh Government brought in new levels of India-American co-operation which troubled the Chinese, thinking that India would become a part of an American 'containment' policy. Another cause of concern was when India tested the Agni-5 ICBM in April 2012, expanding the scope of India's nuclear deterrent and bringing the whole of China in range for the first time. Narendra Modi was quite vocal about the territorial dispute with China during his campaign stating that China should give up its policy of expansion. This has however been considered as campaign trail rhetoric by Chinese foreign experts.

President $\mathrm{Xi}$ Jinping has so far advocated neighbourly diplomacy. Delivering the keynote address at CICA before the leaders of Middle

\footnotetext{
${ }^{\dagger}$ Associate Professor, Department of Economics, Mangaldai College \& Guest Lecturer, Department of Women Studies, Gauhati University, India, Email: chandrama06@gmail.com
}

Eastern, East, South and Central Asian nations, the Chinese President set out his vision of Asia where the principles of respect for sovereignty, independence, territorial integrity and mutual non-interference in internal matters should govern international matters. He further emphasised that for the Asian countries, development is the greatest form of security.

President Xi Xinping's visit to Ahmedabad and to Delhi is likely to have a significant bearing on the stability of relations in the years to come, and on the long-term economic development of both the countries. Modi's win and the BJPled government at the Centre is an added advantage. Modi had already visited China during his tenure as Chief Minister of Gujarat to seek investments and markets for his state and companies. Though Modi was always concerned about security issues with China, he always has admiration for its economic achievements. He now needs China to deliver his campaign promises of growth and development. For the first time, agreements were signed at the regional (Gujarat state) level on development-related issues when Prime Minister Narendra Modi met President Xi Xinping in Ahmedabad. China announced an investment of $\$ 20$ billion in the next five years; this was much less than the expected amount, particularly because India has a huge trade deficit with China. However, this investment can be considered as a breakthrough and the changes can be expected in the years to come.

China is interested on a closer economic relationship with India, particularly in developing the Bangladesh-China-IndiaMyanmar (BCIM) economic corridor and the 'Maritime Silk Road', an oceanic trade route linking China and Europe via South East Asia, India and Africa. Thus, India is an important part of China's vision for economic integration with western Asia and beyond.

If both China and India does not allow the border issue to hamper their relations, one can be sure of positive outcomes for both. Modi 
will get an opportunity to work with Asia's largest economy whereas China needs support from India in its march-west policy and its desire for security in its western region.

This issue of the journal Space and Culture, India has five articles and a book review. The article by Mr Prasenjit Bujar Baruah studies the unorganised sector in Assam. The unorganised sector plays an important role in developing and underdeveloped countries. In India, this sector is not only important in terms of its contribution to national income of the country but also in employment generation. However, the enterprises in this sector face various problems such as small and fluctuating level of income, lack of skill, use of proper technology and most important of all, non-accessibility to credit. In spite of Assam being an agrarian state, the non-farm sector is gaining importance in recent years. However, a large percentage of unorganised enterprises lack adequate amount of capital. Since they are denied institutional credit, they have to depend on non-institutional sources, who exploit them by charging higher interest. And smaller the enterprise, more dependent they are on the non-institutional sources of credit.

Ms Julia Guenther examines the work of two sanghams (collectives) by the Andhra Pradesh Mahila Samatha Society (APMSS) in Sangareddy and Yellareddy, two districts of Telangana. The work consists of songs created by the Dalit and indigenous women, which are used as a form of protest against inequality. The sanghams proves that, despite societal differences, solidarity among women for a common cause can make a difference in combating social issues. Education leads to empowerment. APMSS approach to empowerment and education is a holistic one where apart from literacy sessions, an understanding and analysis of issues, such as a lack of drinking water, legal assistance, etc. are discussed. The study comes up with the finding that literacy is not the only solution to fight for women's rights-what is needed is an understanding of local contexts, social issues and the ability to link them to lifeexperiences.
Mr Biswajit Ghosh and Ms Namita Chakma studies the process of urbanisation in West Bengal in the 19 districts of the state (without the incorporation of the Alipurduar district), from 1981 to 2011. Based on Census data, the study uses the Principal Component Analysis (PCA) to find out the variables affecting urbanisation. It has been found that West Bengal has experienced a high level of urbanisation during 2001-2011, though high inter-district disparities exist. The study finds a high density of urban population in those districts with a high level of economic development. And it is found that the three factors affecting urbanisation are rural-urban displacement, decadal growth rate and rate of urbanisation.

Dr Anuradha Singh in her article Buddhism in Sarnath: An Account of Two Chinese Travellers studies the importance of Sarnath, a place where Lord Gautama Buddha is known to have delivered his first sermon after his enlightenment in Bodhgaya. With the increased popularity of Buddhism in China, the Chinese people started visiting India to study the Buddhist religion and philosophy, and carry home copies of Buddhist compositions. The paper studies the accounts of Fa-Hien and Hiuen-Tsang in Sarnath. Fa-Hien visited India during the reign of Chandragupta II and lived for about 14-15 years. He mentions Sarnath as the place where Buddha gave his first sermon. $\mathrm{He}$ also talks about the stupas and the two sanghams where Buddhist monks used to live. Most of the deities of Buddha during the Gupta period show the importance of Buddhism when Fa-Hien visited India. Hiuen-Tsang visited India during the reign of Harshavardhan and lived in India for about 15 years. He first visited Varanasi, a densely populated city and found people courteous and devotional. He describes in details the life of monks and their way of living during that time.

Dr Sujit Kumar Paul examines the role of DFID (Department for International Development), Government of UK for strengthening decentralisation in rural West Bengal. The 73rd Amendment Act has made panchayats an 
institution of self-government, and Article 243G envisages Panchayats as Institute of Self Governance, which means that they enjoy functional, financial and administrative autonomy in their working area. He stresses the fact that the Gram Panchayats in West Bengal have been given more powers in comparison with powers given to Block/District Panchayats. Encouraged by the West Bengal Government's commitment to rural decentralisation, DFID has come forward to support the decentralisation initiatives. The Programme for Strengthening Rural Decentralisation (SRD) has been carried out with the support from DFID. This has led to the success in rural decentralisation leading to sustainable reduction in poverty in the rural areas of the state. The interventions on SRD mode should start in all tiers of panchayats and in all districts of the state for better outcome in the form of enhanced resource mobilisation, improved financial management, participatory planning, social mobilisation, transparency, inclusiveness and accountability-all leading to reduction of poverty.

Finally, this issue of our journal brings you a book review titled Life and Times of Unborn Kamla written by K.K. Varma and our regular Publication Watch. 